\title{
An unusual titanomagnetite replacing spinel
}

\author{
AAGE JENSEN
}

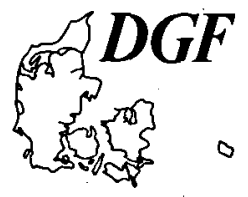

Jensen, Aa. 1993. An unusual titanomagnetite replacing spinel. Bulletin of the
Geological Society of Denmark, Vol. 40, pp. 300--313. Copenhagen 1993-12-30.
https://doi.org/10.37570/bgsd-1993-40-14

In a recent investigation of the Fe-Ti-oxides in the Koster dyke swarm, SW Sweden, one of the dykes from sector I (41197) was omitted because the cubic Fe-Ti-oxides in this dyke were found to deviate from those in all the other dykes.

The Fe-Ti-oxides in 41197 consist partly of ilmenite as free grains, and partly of titanomagnetite with sandwich as well as trellis oxyexsolution lamellae of ilmenite. Some of the titanomagnetite grains have a core of grey spinel, and there are also grains consisting mainly of spinel, but with the spinel clearly being replaced by titanomagnetite.

Electron microprobe analyses of these Fe-Ti-oxides have revealed that the ilmenite as free grains has a composition quite similar to that in the other Koster dykes from sector I. Apart from a small content of $\mathrm{Cr}$, the ilmenite lamellae in the titanomagne-tite grains also show good agreement with the other Koster dykes from sector I, but there are small but significant differences between the ilmenite lamellae from grain to grain within the sample.

The titanomagnetite groundmass also shows small but significant differences be-tween different grains. The composition of the titanomagnetite varies from ferrofer-rites to ferrochromferrites.

The grey spinel varies from ferrospinel over ferrochromspinel to ferroferrichromspinel. Except for the spinel grain with only incipient replacement by titanomagne-tite, the spinels have a rim which is richer in $\mathrm{Mg}, \mathrm{Al}$ and $\mathrm{Zn}$ and poorer in $\mathrm{Cr}$ and $\mathrm{Fe}^{+++}$than the core.

Temperature and $\mathrm{fO}_{2}$ of coexisting pairs of ilmenite and titanomagnetite varies from $991^{\circ} \mathrm{C}, \mathrm{fO}_{2} 10^{-12.9}$, to $1104^{\circ} \mathrm{C}, \mathrm{fO}_{2} 10^{-11.2}$.

Aage Jensen, Department of Mineralogy, University of Copenhagen, Øster Voldgade 10, DK-1350 Copenhagen K, Denmark, July 31th 1991.

\section{Introduction}

The petrology, geochemistry and structural geology of the Koster dyke swarm, SW Sweden, has been thoroughly dealt with by Hageskov $(1984,1985,1987)$. The Fe-Ti-oxides in the Koster dykes were the object of a separate study by Jensen (1990). In this investigation, however, one of the dykes (41197) from sector I (Hageskov 1984) was omitted, because the cubic Fe-Ti-oxides in this dyke were found to deviate from those in all the other dykes. The dyke in question is an olivine-porhyritic dyke; Hageskov (1987) mentions that about $5-10 \%$ of the Koster dykes are porphyritic, and he omitted these from his geochemical studies.

The Fe-Ti-oxides in 41197 consist of ilmenite as free grains and titanomagnetite with sandwich as well as trellis oxyexsolution lamellae of ilmenite; the titanomagnetite grains sometimes have a core of grey spinel.

During the investigation by Jensen (1990) electron microprobe analyses of one such spinel core, the ilme- nite lamellae and titanomagnetite groundmass in the titanomagnetite surrounding the spinel core, ilmenite lamellae, and titanomagnetite groundmass in neighbouring titanomagnetite grains without spinel cores, and ilmenite as free grains were carried out, but not published. The grain with spinel core is referred to as grain 0 .

Further investigation has shown that although only some titanomagnetite grains have a core of spinel, there are also grains having a texture that clearly shows that titanomagnetite has replaced spinel. New electron microprobe analyses have been carried out on the spinel, ilmenite lamellae and titanomagnetite groundmass of four such grains, in the following referred to as grains 1 , 2, 3 and 4.

Grain 0 is shown in fig. 1; grain 1 with only incipient replacement of spinel by titanomagnetite is shown in fig. 2, and grain 4 with more advanced replacement of spinel by titanomagnetite is shown in fig. 3 .

In grain 1 the spinel seems homogeneous from core to rim, whereas all the other grains have rims that are 


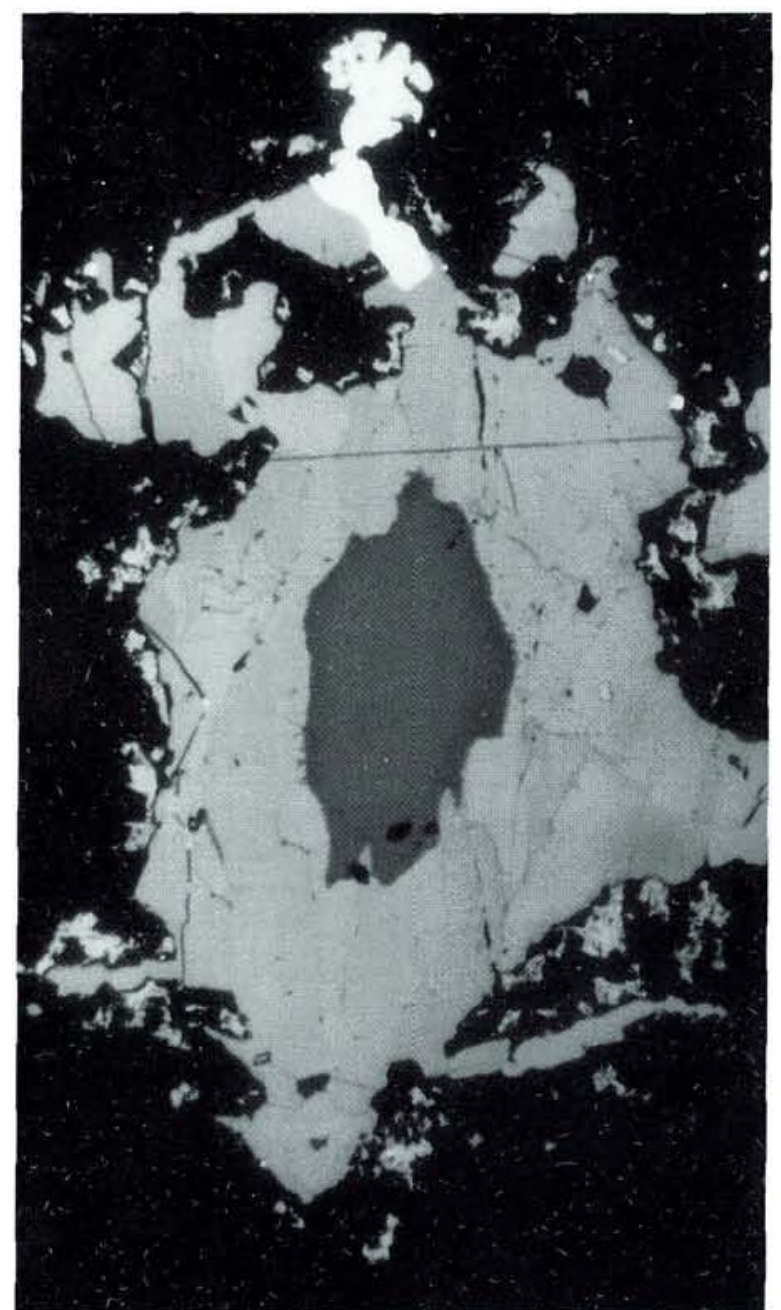

Fig, 1. Grain 0, Oil immersion. $\times 230$. Titanomagnetite grain with spinel core.

more or less darker than the cores. However, only for grains 0 and 2 are the electron microprobe analyses differentiated between core and rim, for the other grains only analyses of cores were carried out.

\section{Analytical results}

The electron microprobe analyses (WDS) were carried out with a Jeol Superprobe JCXA 733 with $15.0 \mathrm{kV}$ accelerating voltage and a sample current of $20.0 \mathrm{nA}$ using olivine, corundum, rutile, $\mathrm{V}_{2} \mathrm{O}_{3}, \mathrm{Cr}_{2} \mathrm{O}_{3}, \mathrm{MnTiO}_{3}$, hematite, $\mathrm{Ni}$ and $\mathrm{ZnO}$ as standards. Total iron was distributed between ferrous and ferric iron using the method suggested by Finger (1972).

The results for $\mathrm{Fe}$-Ti-oxides are shown in tables 1 to 4 and for olivine in table 5.

\section{Spinel analyses}

The results of the electron microprobe analyses of spinel are shown in table 1. It can be seen that the spinel in grain 0, core as well as rim, is significantly poorer in $\mathrm{Mg}$ than all the other grains. Grain 0 is lower in $\mathrm{Al}$ than grains 1,3 and 4 , and the rim of grain 0 is lower than the rim of grain 2, but the core of grain 2 is not significantly different from the core of grain 0 . The rim of grain 2 is low in $\mathrm{Ti}$, but otherwise there are no significant differences in $\mathrm{Ti}$. $\mathrm{TiO}_{2}$ versus $\mathrm{Mg} / \mathrm{Mg}+\mathrm{Fe}^{++}$is shown in fig. 4 .

Grain 0 is higher in $\mathrm{V}$ than grains 1,2 and 4 , but is not significantly different from grain 3 . It is higher in $\mathrm{Cr}$ than grains 1,3 and 4 , and the rim of grain 0 is higher than the rim of grain 2, but core of grain 0 is not significantly different from core of grain 2 .

There are no significant differences in Mn.

Grain 0 is higher in $\mathrm{Fe}^{++}$than all the other grains, and higher in $\mathrm{Fe}^{+++}$than grain 3, but is not significantly different from the other grains as regards $\mathrm{Fe}^{+++}$.

There are no significant differences in $\mathrm{Ni}$.

Grain 0 is higher in $\mathrm{Zn}$ than grains 1 and 3, but is not significantly different from grains 2 and 4 .

The rims in grains 0 and 2 are richer in $\mathrm{Mg}, \mathrm{Al}$ and $\mathrm{Zn}$ and poorer in $\mathrm{Cr}$ and $\mathrm{Fe}^{+++}$than the cores.

According to the terminology of ZhelyazkovaPanayotova (1971) grains 1 and 4 and the cores of grains 0 and 2 are ferroferrichromspinels, grain 3 and the rim of grain 0 are ferrochromspinels, and the rim of grain 2 is ferrospinel.

\section{Ilmenite analyses}

The results of the electron microprobe analyses of ilmenite are shown in table 2 . The table comprises analyses of ilmenite lamellae in grains 1, 2, 3 and 4 as well as analyses of ilmenite as free grains. However, the second column labelled "Lamellae Grain 0" presents averages for ilmenite lamellae both in grain 0 and in neighbouring titanomagnetite grains without a spinel core.

It is clearly seen from the table that there are no significant differences between these ilmenite lamellae ("Grain 0") and ilmenite occurring as free grains. Therefore, in the following, comparisons are made only between the grains 1,2,3 and 4 and ilmenite as free grains.

No variations are found for $\mathrm{Al}, \mathrm{V}, \mathrm{Ni}$ and $\mathrm{Zn}$, which if present at all occur only in very small amounts.

Ilmenite lamellae in all four grains are higher in $\mathrm{Mg}$ than ilmenite as free grains, and $\mathrm{Mg}$ varies from 0.019 in grain 4 to 0.057 in grain 1 (all figures for contents of elements are for cations based on $32 \mathrm{O}$ ).

Likewise $\mathrm{Cr}$ is higher in the lamellae in all four grains 


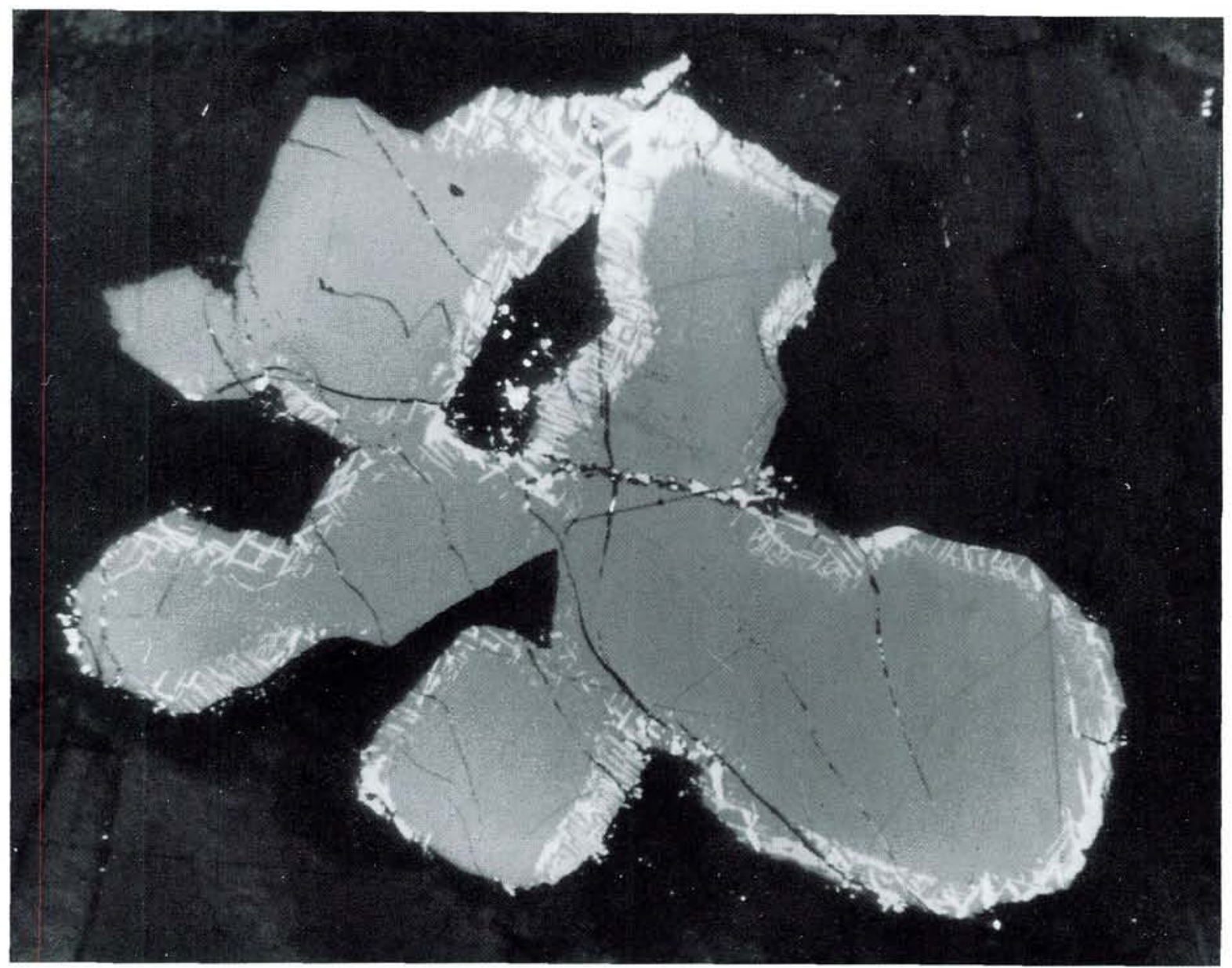

Fig. 2. Grain 1. Oil immersion. $\times 230$. Spinel grain with incipient replacement by titanomagnetite.

than in ilmenite as free grains, and $\mathrm{Cr}$ varies from 0.007 in grain 2 to 0.028 in grain 1 .

Lamellae in grain 2 are higher in Ti than ilmenite as free grains, whereas lamellae in grain 4 , because of the higher standard deviation, are only higher than free grains in the confidence level between 0.975 and 0.99 . $\mathrm{TiO}_{2}$ versus $\mathrm{Mg} / \mathrm{Mg}+\mathrm{Fe}^{++}$for ilmenite is shown in fig. 5 .

Ilmenite lamellae in grain 3 are higher in $\mathrm{Mn}$ than ilmenite as free grains, but otherwise there are no significant differences. Mn varies from 0.016 to 0.021 .

Ilmenite lamellae in grains 1 and 3 are lower in $\mathrm{Fe}^{++}$ than ilmenite as free grains, whereas lamellae in grains 2

Fig. 3. Grain 4. Oil immersion. $\times 230$. Spinel grain with advanced replacement by titanomagnetite.

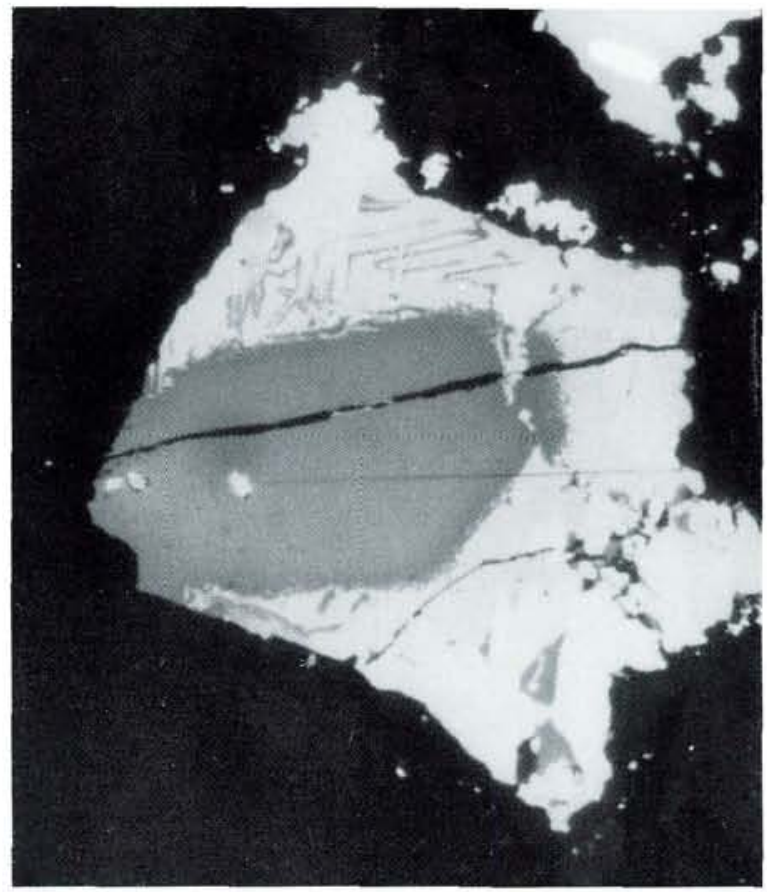

Bulletin of the Geological Society of Denmark 


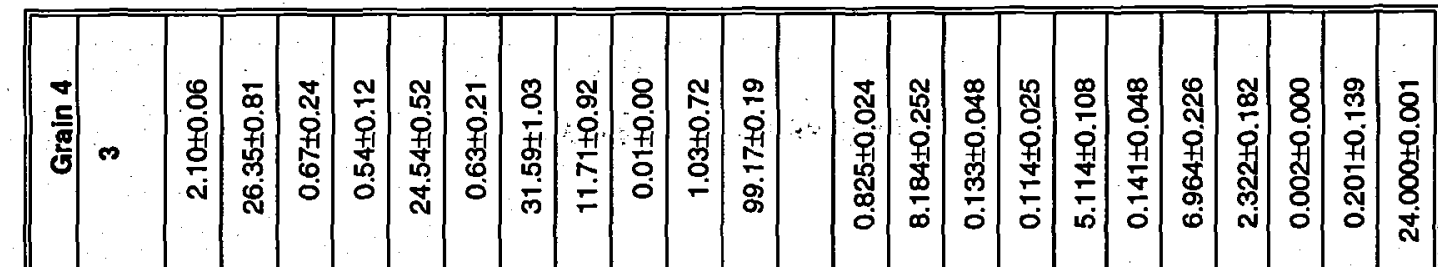

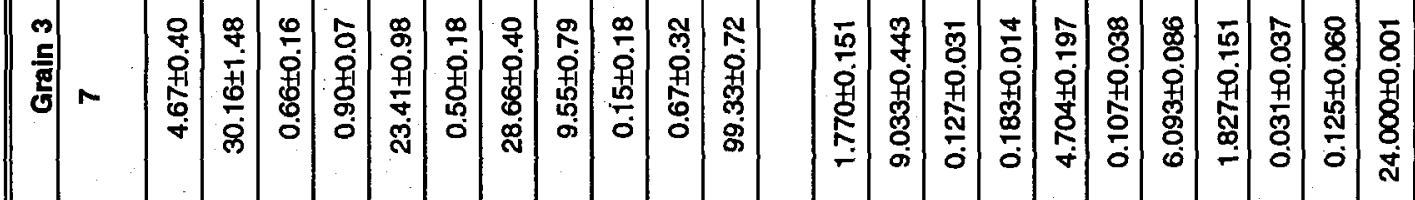

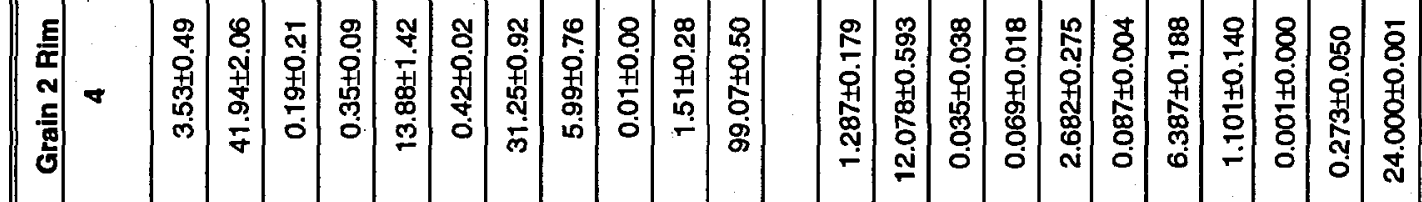

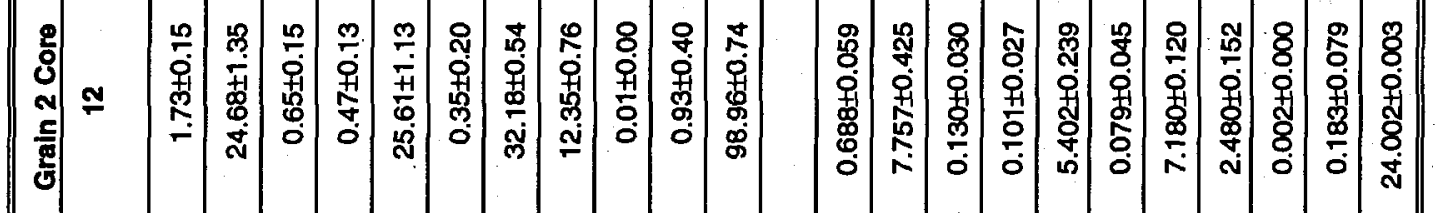

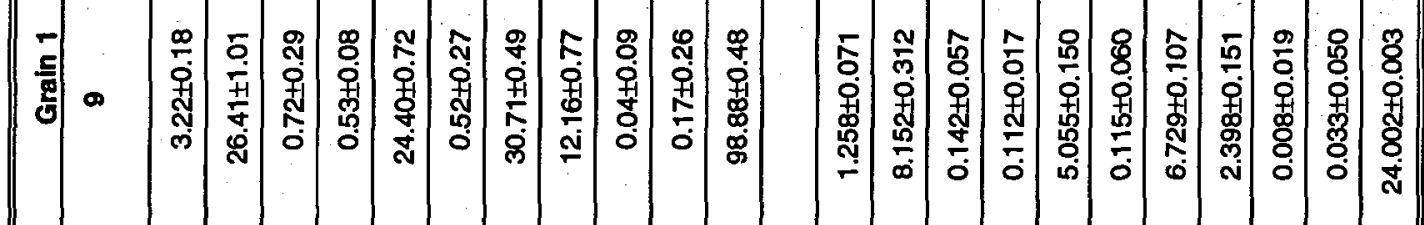

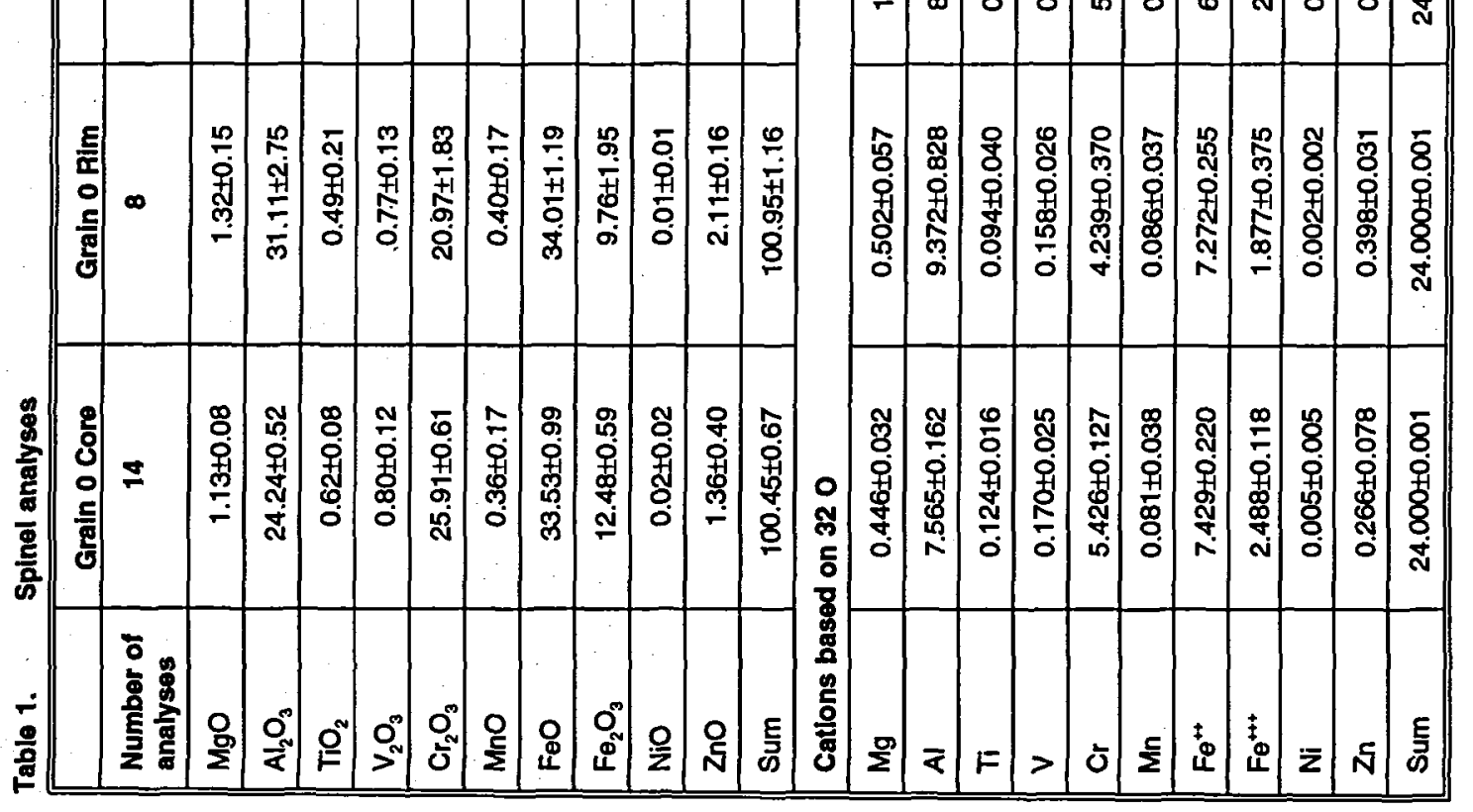




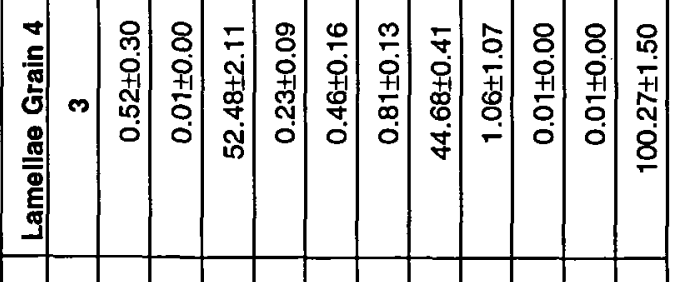

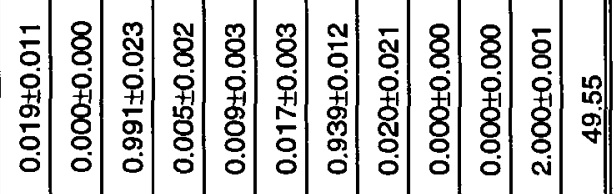

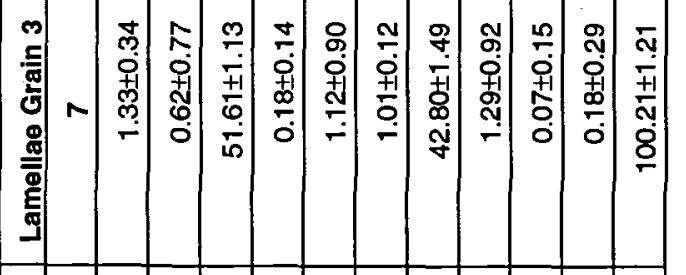

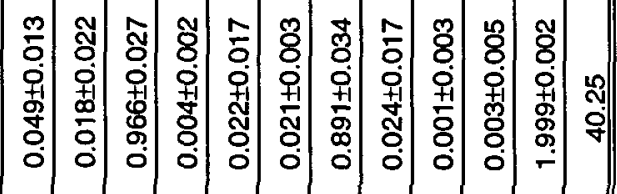

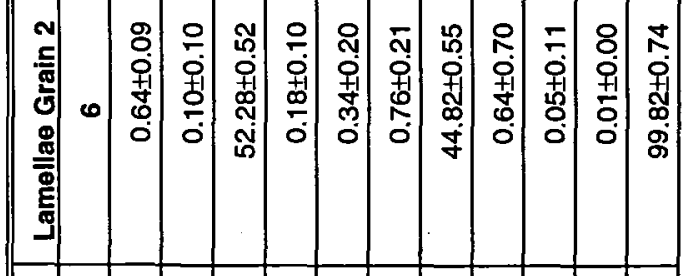

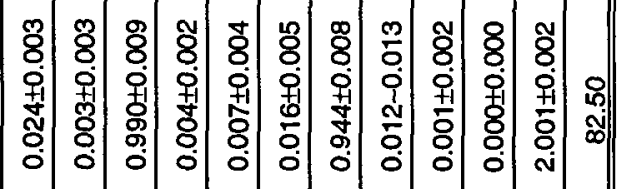

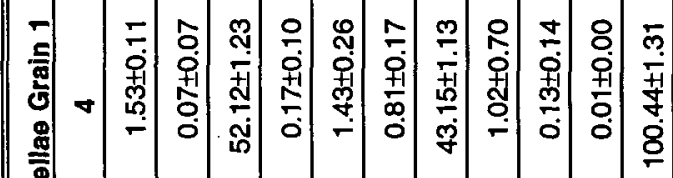

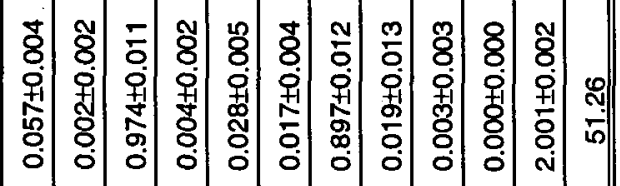

हิ

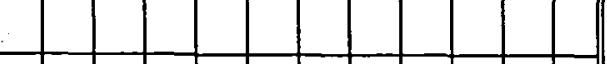

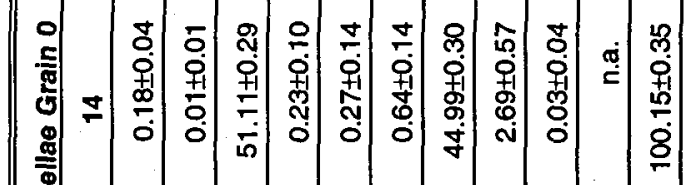

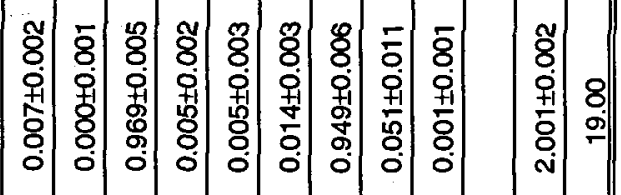

돔

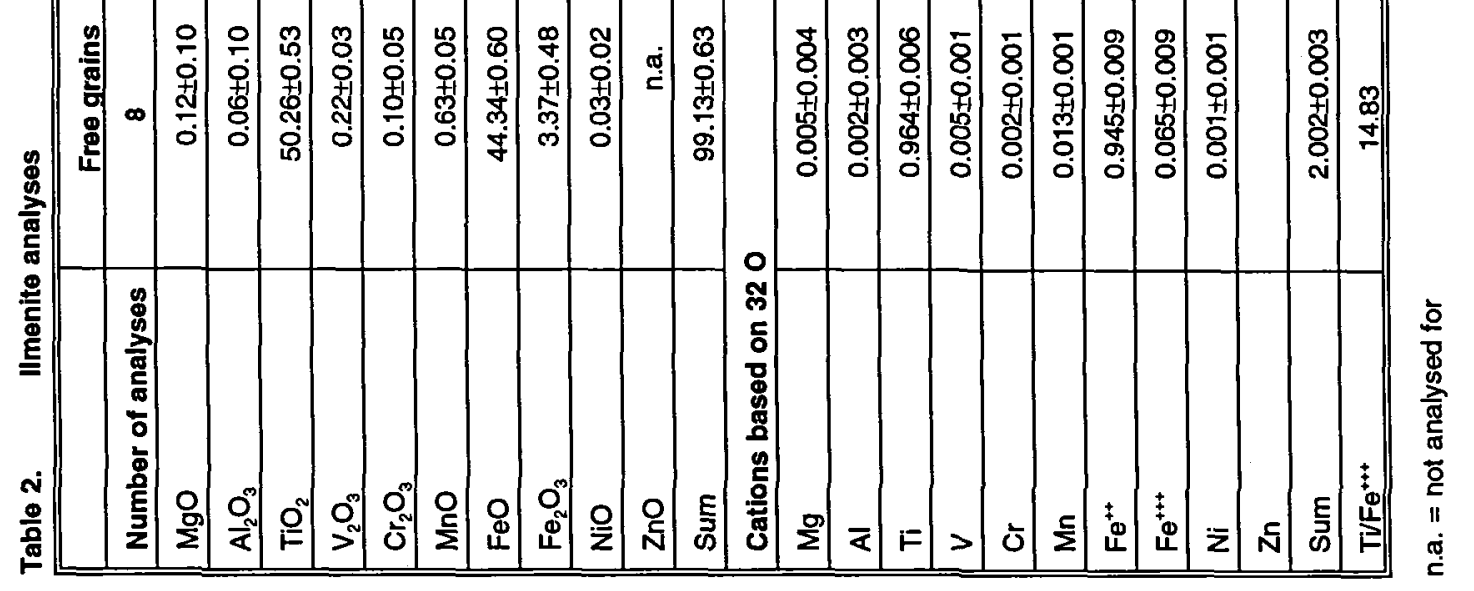




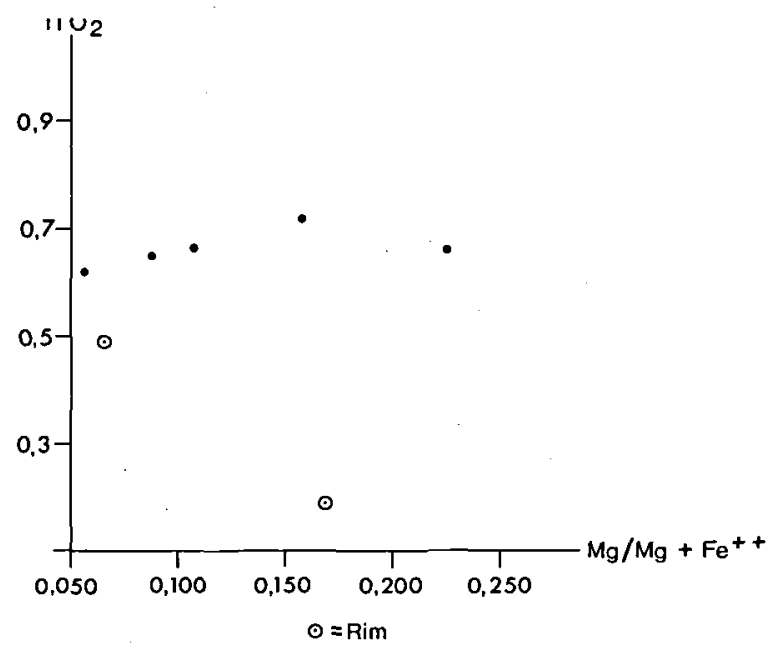

Fig. 4. $\mathrm{TiO}_{2}$ versus $\mathrm{Mg} / \mathrm{Mg}+\mathrm{Fe}^{++}$for spinel analyses.

and 4 are similar to free grains. $\mathrm{Fe}^{++}$varies from 0.891 to 0.944 .

In all four grains ilmenite lamellae are lower in $\mathrm{Fe}^{+++}$ than ilmenite as free grains. $\mathrm{Fe}^{+++}$varies from 0.012 to 0.024 .

\section{Analyses of the titanomagnetite groundmass}

The results of the electron microprobe analyses of titanomagnetite groundmass are shown in table 3 . The first column labelled "Grain 0" is the average of the groundmass in Grain 0 and groundmass of neighbouring titanomagnetite grains without a spinel core.

Mg varies between 0.029 and 0.399 ; grains 1,3 and 4 are higher in $\mathrm{Mg}$ than "Grain 0", whereas grain 2 is not significantly different from "Grain 0 ".

Al varies between 1.023 and 1.834; grain 3 is higher and grain 2 is lower in Al than "Grain 0", whereas grains 1 and 4 are not significantly different from "Grain $0 "$.

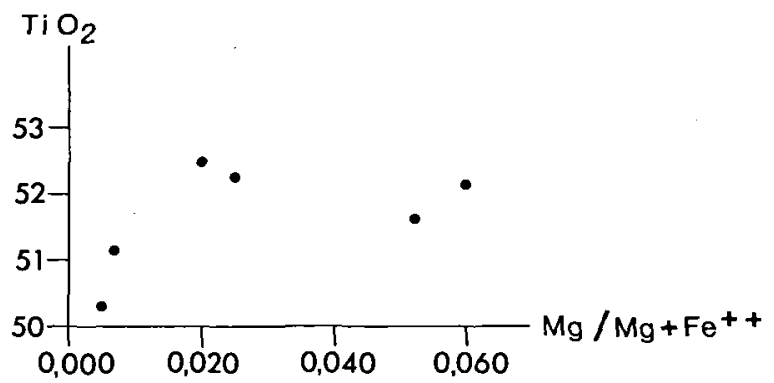

Fig. 5. $\mathrm{TiO}_{2}$ versus $\mathrm{Mg} / \mathrm{Mg}+\mathrm{Fe}^{++}$for ilmenite analyses.

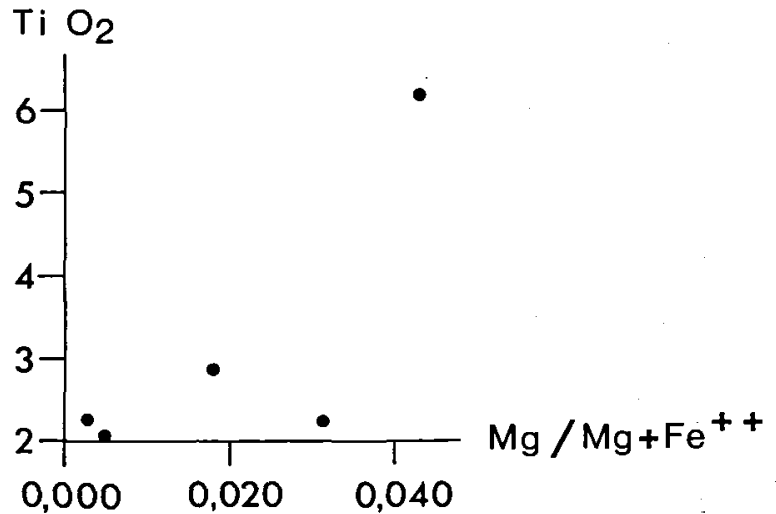

Fig. 6. $\mathrm{TiO}_{2}$ versus $\mathrm{Mg} / \mathrm{Mg}+\mathrm{Fe}^{++}$for analyses of titanomagnetite groundmass.

Ti varies between 0.457 and 1.354 ; grain 3 is higher in Ti than "Grain 0", whereas grains 1,2 and 4 are not significantly different from "Grain 0 ". $\mathrm{TiO}_{2}$ versus $\mathrm{Mg} /$ $\mathrm{Mg}+\mathrm{Fe}^{++}$for the titanomagnetite groundmass is shown in fig. 6 .

$V$ varies between 0.286 and 0.607 ; grains 1,2 and 4 are lower in V than "Grain 0", but grain 3 is not significantly different.

$\mathrm{Cr}$ varies between 1.824 and 4.007 ; grains 1,3 and 4 are higher and grain 2 is lower in Cr than "Grain 0".

$\mathrm{Mn}$ varies between 0.041 and 0.148 ; grains 1,3 and 4 are higher in Mn than "Grain 0", whereas grain 2 is not significantly different.

$\mathrm{Fe}^{++}$varies between 8.038 and 8.778 ; grain 3 is higher and grain 1 is lower in $\mathrm{Fe}^{++}$than "Grain 0", whereas grains 2 and 4 are not significantly different.

$\mathrm{Fe}^{+++}$varies between 6.858 and 11.782 ; grains 1,3 and 4 are lower and grain 2 is higher in $\mathrm{Fe}^{+++}$than "Grain 0".

There are no significant differences in $\mathrm{Ni}$ and $\mathrm{Zn}$.

According to the terminology of ZhelyazkovaPanayotova (1971) grains 1, 3 and 4 are ferrochromferrites, whereas grains 0 and 2 are ferroferrites.

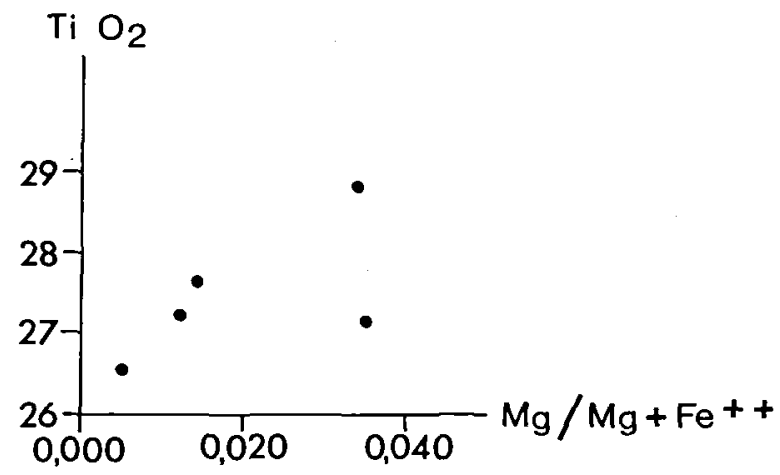

Fig. 7. $\mathrm{TiO}_{2}$ versus $\mathrm{Mg} / \mathrm{Mg}+\mathrm{Fe}^{++}$for the calculated composition of the original titanomagnetite. 


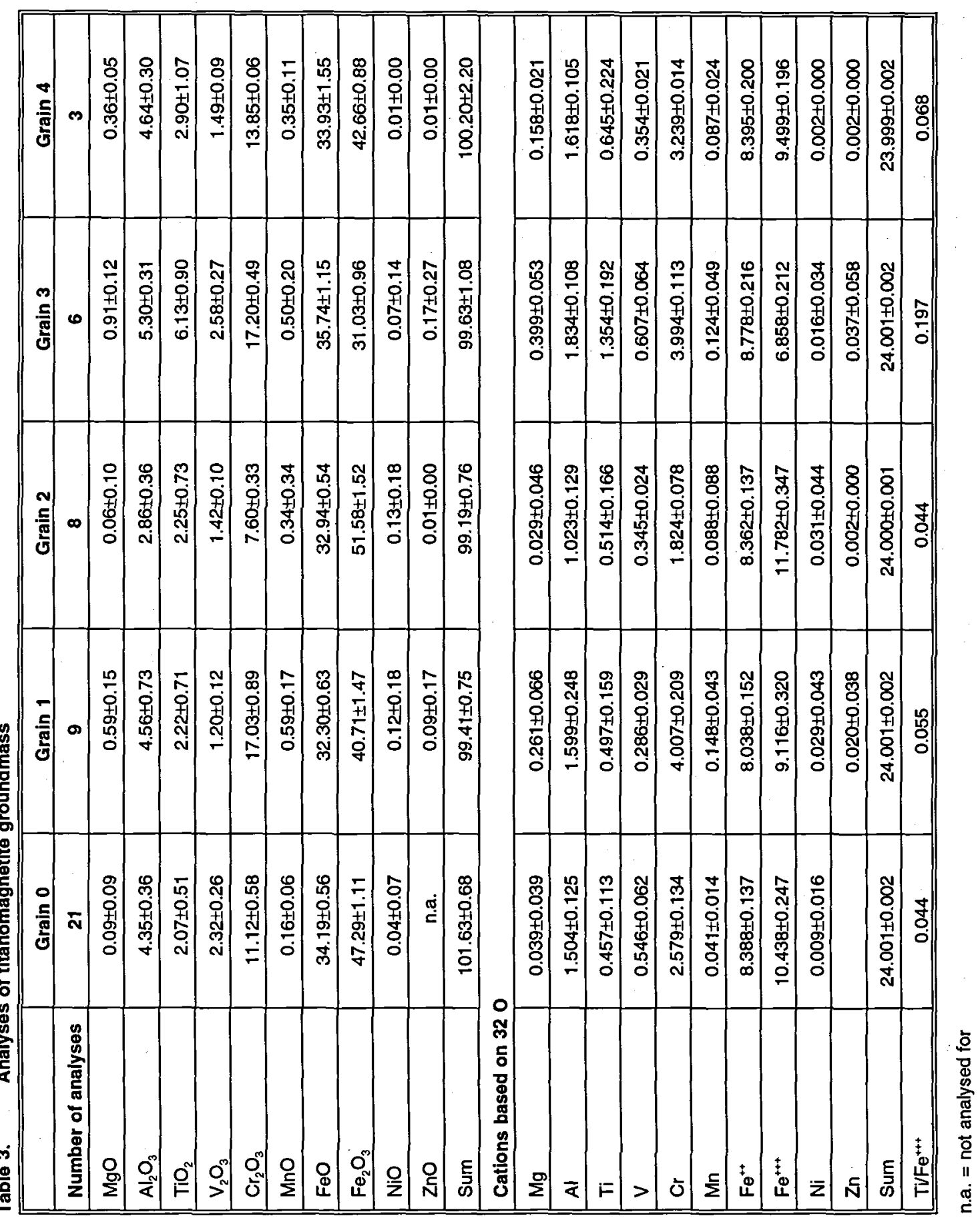




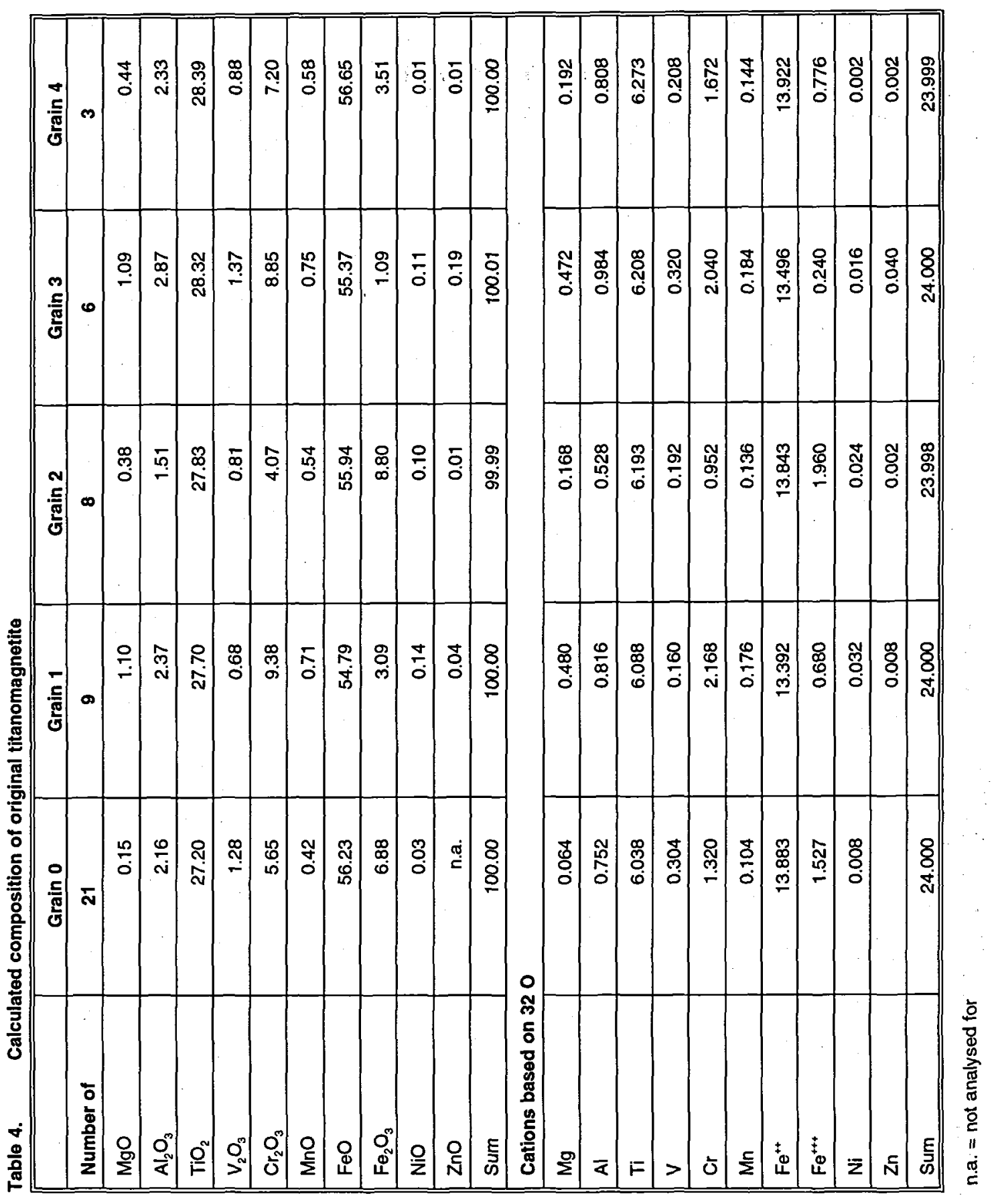


Table 5.

Olivine analyses

Column I:

Column II:

Large olivine phenocrysts

Column III:

Small olivine phenocrysts

Olivine groundmass grains

\begin{tabular}{||l|c|c|c||}
\hline & 1 & II & III \\
\hline Number of analyses & 5 & 4 & 5 \\
\hline $\mathrm{SiO}_{2}$ & $38.78 \pm 0.11$ & $37.29 \pm 0.50$ & $36.00 \pm 0.42$ \\
\hline $\mathrm{TiO}_{2}$ & $0.01 \pm 0.00$ & $0.01 \pm 0.00$ & $0.08 \pm 0.10$ \\
\hline $\mathrm{FeO}$ & $20.38 \pm 0.71$ & $30.24 \pm 2.62$ & $36.49 \pm 0.43$ \\
\hline $\mathrm{MnO}$ & $0.20 \pm 0.13$ & $0.26 \pm 0.10$ & $0.37 \pm 0.08$ \\
\hline $\mathrm{MgO}$ & $40.26 \pm 0.57$ & $32.63 \pm 2.12$ & $27.31 \pm 0.30$ \\
\hline $\mathrm{CaO}$ & $0.06 \pm 0.07$ & $0.07 \pm 0.12$ & $0.08 \pm 0.11$ \\
\hline $\mathrm{Cr} \mathrm{O}_{3}$ & $0.04 \pm 0.05$ & $0.01 \pm 0.00$ & $0.03 \pm 0.05$ \\
\hline $\mathrm{NiO}$ & $0.21 \pm 0.19$ & $0.14 \pm 0.15$ & $0.06 \pm 0.10$ \\
\hline $\mathrm{Sum}$ & $99.94 \pm 0.28$ & $100.65 \pm 0.84$ & $100.42 \pm 0.48$ \\
\hline $\mathrm{Cations}$ based on sum of $3:$ & & & \\
\hline $\mathrm{Si}$ & $1.000 \pm 0.002$ & $1.002 \pm 0.005$ & $1.002 \pm 0.009$ \\
\hline $\mathrm{Ti}$ & $0.000 \pm 0.000$ & $0.000 \pm 0.000$ & $0.002 \pm 0.002$ \\
\hline $\mathrm{Fe}{ }^{++}$ & $0.440 \pm 0.016$ & $0.680 \pm 0.066$ & $0.850 \pm 0.015$ \\
\hline $\mathrm{Mn}$ & $0.004 \pm 0.003$ & $0.006 \pm 0.003$ & $0.009 \pm 0.002$ \\
\hline $\mathrm{Mg}$ & $1.548 \pm 0.020$ & $1.307 \pm 0.072$ & $1.133 \pm 0.007$ \\
\hline $\mathrm{Ca}$ & $0.001 \pm 0.002$ & $0.002 \pm 0.003$ & $0.002 \pm 0.003$ \\
\hline $\mathrm{Cr}$ & $0.001 \pm 0.001$ & $0.000 \pm 0.000$ & $0.001 \pm 0.001$ \\
\hline $\mathrm{Ni}$ & $0.004 \pm 0.004$ & $0.003 \pm 0.003$ & $0.001 \pm 0.003$ \\
\hline $\mathrm{Oxygen}$ & $4.001 \pm 0.002$ & $4.002 \pm 0.005$ & $4.004 \pm 0.010$ \\
\hline $\mathrm{Mg} / \mathrm{Mg}+\mathrm{Fe}$ & $0.779 \pm 0.008$ & $0.657 \pm 0.034$ & $0.572 \pm 0.005$ \\
\hline & & & \\
\hline
\end{tabular}

\section{Comparisons between analyses of spinel, ilmenite and titanomagnetite}

There is a positive correlation between spinel and titanomagnetite groundmass for $\mathrm{Mg}, \mathrm{V}$ and $\mathrm{Fe}^{+++}$, and a negative correlation for $\mathrm{Cr}$.
There is also a positive correlation between spinel, ilmenite lamellae and titanomagnetite groundmass for total Fe.

There is a positive correlation between spinel and ilmenite lamellae for $\mathrm{Mg}, \mathrm{Al}$ and $\mathrm{Fe}^{++}$, and possibly a negative correlation for $\mathrm{Cr}$.

There is a positive correlation between titanomagnetite groundmass and ilmenite lamellae for $\mathrm{Mg}$ and $\mathrm{Cr}$.

Bulletin of the Geological Society of Denmark 
Table 6.

\begin{tabular}{|c|c|c|c|c|c|c|}
\hline . & \multicolumn{2}{|c|}{41197} & \multicolumn{2}{|c|}{$\begin{array}{c}\text { Least } \\
\text { Differentiated } \\
\text { Koster Dyke } \\
\text { Sector I }\end{array}$} & \multicolumn{2}{|c|}{$\begin{array}{c}\text { Mean Koster } \\
\text { Dyke } \\
\text { Sector I }\end{array}$} \\
\hline $\mathrm{SiO}_{2}$ & & 46.770 & & 47.85 & \multicolumn{2}{|c|}{$48.11 \pm 0.40$} \\
\hline $\mathrm{TiO}_{2}$ & & 1.723 & & 1.97 & \multicolumn{2}{|c|}{$2.52 \pm 0.41$} \\
\hline $\mathrm{Al}_{2} \mathrm{O}_{3} \ldots$ & & 14.140 & & 15.63 & \multicolumn{2}{|c|}{$14.41 \pm 0.99$} \\
\hline $\mathrm{Fe}_{2} \mathrm{O}_{3} \ldots$ & & 1.917 & & 1.51 & \multicolumn{2}{|c|}{$2.46 \pm 0.57$} \\
\hline $\mathrm{FeO}$ & & 11.620 & & 11.57 & \multicolumn{2}{|c|}{$12.17 \pm 0.76$} \\
\hline $\mathrm{MnO}$ & & 0.202 & & 0.19 & \multicolumn{2}{|c|}{$0.21 \pm 0.02$} \\
\hline $\mathrm{MgO}$ & & 10.770 & & 8.01 & \multicolumn{2}{|c|}{$6.88 \pm 0.75$} \\
\hline $\mathrm{CaO}$ & & 9.240 & & 10.06 & \multicolumn{2}{|c|}{$9.76 \pm 0.33$} \\
\hline $\mathrm{Na}_{2} \mathrm{O}$ & & 2.110 & & 2.31 & \multicolumn{2}{|c|}{$2.27 \pm 0.44$} \\
\hline $\mathrm{K}_{2} \mathrm{O}$ & & 0.495 & & 0.56 & \multicolumn{2}{|c|}{$0.74 \pm 0.15$} \\
\hline $\mathrm{H}_{2} \mathrm{O}$ & & 1.133 & & 0.76 & \multicolumn{2}{|c|}{$0.85 \pm 0.35$} \\
\hline $\mathrm{P}_{2} \mathrm{O}_{5}$ & & 0.382 & & 0.36 & \multicolumn{2}{|c|}{$0.47 \pm 0.09$} \\
\hline Sum & & 100.502 & & 100.78 & \multicolumn{2}{|c|}{100.85} \\
\hline $\mathrm{FeO}^{\circ}$ & & 13.34 & & 12.93 & \multicolumn{2}{|c|}{$14.39 \pm 1.03$} \\
\hline $\mathrm{FeO} / \mathrm{MgO}$ & & 1.24 & & 1.61 & \multicolumn{2}{|c|}{$2.13 \pm 0.40$} \\
\hline $\mathrm{Fe}_{2} \mathrm{O}_{3} / \mathrm{FeO}$ & & 0.16 & & 0.13 & \multicolumn{2}{|c|}{$0.20 \pm 0.05$} \\
\hline \multicolumn{7}{|c|}{ C.I.P.W. weight norms } \\
\hline $\mathbf{Q}$ & 0.00 & 0.00 & 0.00 & 0.00 & 0.00 & 0.00 \\
\hline or & 3.10 & 3.10 & 3.35 & 3.35 & 4.55 & 4.55 \\
\hline$a b$ & 19.10 & 19.10 & 21.10 & 21.10 & 20.75 & 20.75 \\
\hline an & 27.75 & 27.75 & 30.79 & 30.79 & 27.55 & 27.55 \\
\hline \multirow{3}{*}{$\begin{array}{l}\text { wo } \\
\text { en di }\end{array}$} & 6.48 & 6.48 & 6.86 & 6.86 & 7.40 & 7.40 \\
\hline & 4.35 & 4.31 & 4.17 & 4.21 & 4.28 & 4.14 \\
\hline & 2.13 & 2.17 & 2.69 & 2.65 & 3.12 & 3.26 \\
\hline \multirow{2}{*}{ en hy } & 8.63 & 8.34 & 8.28 & 8.55 & 12.52 & 11.44 \\
\hline & 4.23 & 4.18 & 5.34 & 5.39 & 9.12 & 9.02 \\
\hline \multirow{2}{*}{ fo } & 12.74 & 12.98 & 7.44 & 7.21 & 1.96 & 2.88 \\
\hline & 6.25 & 6.52 & 4.80 & 4.55 & 1.43 & 2.28 \\
\hline $\mathrm{mt}$ & 2.03 & 1.85 & 1.61 & 1.77 & 2.64 & 2.04 \\
\hline ii & 2.46 & 2.46 & 2.82 & 2.82 & 3.64 & 3.64 \\
\hline ap & 0.75 & 0.75 & 0.75 & 0.75 & 1.07 & 1.07 \\
\hline
\end{tabular}




\section{Determination of the composition of the original titanomagnetite}

Microscopic investigation has revealed that in all the grains the ratio of the volume of ilmenite lamellae to titanomagnetite groundmass is very close to $1: 1$. No visible deviation from this ratio can be detected, so the following calculation is based on the assumption that oxyexsolved ilmenite and titanomagnetite groundmass are present in equal amounts.

The cations from the electron microprobe analyses of the ilmenite lamellae have been recalculated from sum of cations 2 to sum of cations 3 . Then the average of this and the cations from the microprobe analyses of the titanomagnetite groundmass was calculated. The result was calibrated to 4 oxygens with corresponding movement of $\mathrm{Fe}^{+++}$to $\mathrm{Fe}^{++}$. The ratio of ulvöspinel to magnetite was then determined from this result.

Grain 3 is low in $\mathrm{Fe}$ in both ilmenite lamellae and titanomagnetite groundmass, and when calculating the original titanomagnetite of grain 3 there is not enough Fe to make $\mathrm{Fe}_{2} \mathrm{TiO}_{4}, \mathrm{FeCr}_{2} \mathrm{O}_{4}, \mathrm{FeAl}_{2} \mathrm{O}_{4}$ and $\mathrm{FeV}_{2} \mathrm{O}_{4}$ from the amounts of $\mathrm{Ti}, \mathrm{Cr}, \mathrm{Al}$ and $\mathrm{V}$ present. However, the deficiency is within the standard deviation of $\mathrm{Fe}^{++}$and $\mathrm{Fe}^{+++}$. The determination of the composition of the original titanomagnetite in grain 3 is therefore based on the average values of $\mathrm{Fe}^{++}$and $\mathrm{Fe}^{+++}$increased with the standard deviation.

The calculated composition of the original titanomagnetite is shown in table 4 , and $\mathrm{TiO}_{2}$ versus $\mathrm{Mg}$ / $\mathrm{Mg}+\mathrm{Fe}^{++}$in fig. 7 .

\section{Temperature and $\mathrm{fO}_{2}$ determinations from coexisting pairs of ilmenite and titanomagnetite}

Temperature and $\mathrm{fO}_{2}$ values are based on the curve for the Akimoto model of Andersen \& Lindsley (1988).

The percentage of $\mathrm{FeTiO}_{3}$ present in the ilmenite is based on the percentage of $\mathrm{Fe}^{++}$present in the electron microprobe analyses of ilmenite as free grains. The percentage of $\mathrm{Fe}_{2} \mathrm{TiO}_{4}$ in the titanomagnetite is based on the percentage of $\mathrm{Ti}$ in the calculated composition of the original titanomagnetite.

Prior to the work of Ghiorso \& Sack (1991) there existed no investigations that told how to handle $\mathrm{Cr}, \mathrm{Al}$ and $\mathrm{V}$ when determining the ratio between $\mathrm{Fe}_{2} \mathrm{TiO}_{4}$ and $\mathrm{Fe}_{3} \mathrm{O}_{4}$ for use in determining temperature and $\mathrm{fO}_{2}$ of coexisting pairs of ilmenite and titanomagnetite.
In the previous study (Jensen 1990) the amount of $\mathrm{Fe}_{2} \mathrm{TiO}_{4}$ was determined as 100 minus the percentage of $\mathrm{Fe}_{3} \mathrm{O}_{4}$, which means that $\mathrm{Cr}, \mathrm{Al}$ and $\mathrm{V}$ were calculated as equivalent to $\mathrm{Ti}$.

This was done in the belief that the presence of $\mathrm{Cr}, \mathrm{Al}$ and $\mathrm{V}$ indicates high temperature, and the higher the percentage of $\mathrm{Fe}_{2} \mathrm{TiO}_{4}$, the higher the values for temperature obtained.

However, if the same procedure (100 minus the percentage of $\mathrm{Fe}_{3} \mathrm{O}_{4}$ ) is used with the $\mathrm{Cr}$-, Al- and V-rich titanomagnetites analysed in this study, the corresponding values of $\mathrm{FeTiO}_{3}$ and $\mathrm{Fe}_{2} \mathrm{TiO}_{4}$ fall outside the curves of Andersen \& Lindsley (1988). Therefore in this study the percentage of $\mathrm{Fe}_{2} \mathrm{TiO}_{4}$ is based only on the percentage of $\mathrm{Ti}$ in the original titanomagnetite.

The result is a range in temperature from $1042^{\circ} \mathrm{C}$ to $1096^{\circ} \mathrm{C}$ and in $\mathrm{fO}_{2}$ from $10^{-11.5}$ to $10^{-10.7}$.

Ghiorso \& Sack (1991) have made a programme which in determining temperature and $\mathrm{fO}_{2}$ of coexisting pairs of ilmenite and titanomagnetite takes $\mathrm{Si}, \mathrm{Ti}, \mathrm{Al}$, $\mathrm{V}, \mathrm{Cr}, \mathrm{Fe}, \mathrm{Mn}, \mathrm{Mg}, \mathrm{Ca}, \mathrm{Zn}$ and $\mathrm{Ni}$ into consideration. Using this programme ranges of $991^{\circ} \mathrm{C}-1104^{\circ} \mathrm{C}$ and $10^{-12.9}-10^{-11.2}$ for temperature and $\mathrm{fO}_{2}$ respectively were obtained.

If the percentages of $\mathrm{Fe}_{2} \mathrm{TiO}_{4}$ based on the results of Jensen (1990) are also based only on the percentage of $\mathrm{Ti}$, the values $1100^{\circ} \mathrm{C}-1280^{\circ} \mathrm{C}$ and $10^{-10}-10^{-8}$ given by Jensen (1990) are changed to $980^{\circ} \mathrm{C}-1210^{\circ} \mathrm{C}$ and $10^{-11}-10^{-9}$ respectively, whereas the programme of Ghiorso \& Sack (1991) gives $746^{\circ} \mathrm{C}-1021^{\circ} \mathrm{C}$ and $\mathrm{fO}_{2}$ $10^{-18.2}-10^{-11.5}$.

\section{Olivine analyses}

Table 5 shows electron microprobe analyses of olivine, somewhat arbitrarily classed as large phenocrysts, small phenocrysts and groundmass grains respectively.

It can be clearly seen that $\mathrm{FeO}$ increases and $\mathrm{MgO}$ decreases with decreasing grain size of the olivine. Unfortunately, however, the low content of $\mathrm{MgO}$ in the spinels prevents the use of the olivine-spinel geothermometer.

\section{Whole rock analyses}

\section{Major elements}

41197 has been analysed in the laboratory of the Geological Survey of Greenland by Ib Sørensen. $\mathrm{H}_{2} \mathrm{O}^{+}$ was determined by the Penfield method and $\mathrm{Fe}^{++}$by wet chemistry. $\mathrm{Mg}$ was determined by complexometric titration, $\mathrm{Na}$ by flame photometry, and the remaining elements were analysed by XRF on glass discs.

The results are shown in table 6 together with the 
Table 7

\begin{tabular}{|c|c|c|c|}
\hline & 41197 & $\begin{array}{l}\text { Least Differentiated } \\
\text { Koster Dyke Sector I }\end{array}$ & $\begin{array}{c}\text { Mean Koster Dyke } \\
\text { Sector } 1\end{array}$ \\
\hline $\mathrm{Rb}$ & 15 & 15 & $24 \pm 8.6$ \\
\hline $\mathrm{Ba}$ & 168 & 280 & $303 \pm 116.8$ \\
\hline Sr & 139 & 171 & $162 \pm 19.7$ \\
\hline La & 14 & 8 & $13 \pm 4.9$ \\
\hline Y & 35 & 39 & $51 \pm 9.0$ \\
\hline $\mathrm{Zr}$ & 167 & 169 & . $224 \pm 40.7$ \\
\hline $\mathrm{Nb}$ & 10 & 9.6 & $11.6 \pm 2.2$ \\
\hline $\mathrm{Ni}$ & 197 & 114 & $83 \pm 22.2$ \\
\hline V & 242 & 282 & $331 \pm 44.6$ \\
\hline \multirow[t]{2}{*}{$\mathrm{Cr}$} & 440 & 287 & $206 \pm 59.7$ \\
\hline & $\mathrm{Zr} / \mathrm{Nb}$ & $\mathrm{Zr} / \mathrm{Y}$ & $\mathrm{Y} / \mathrm{Nb}$ \\
\hline 41197 & 16.7 & 4.8 & 3.5 \\
\hline $\begin{array}{l}\text { Least Differentiated } \\
\text { Koster Dyke Sector I }\end{array}$ & 17.6 & 4.33 & 4.06 \\
\hline $\begin{array}{l}\text { Mean Koster Dyke } \\
\text { Sector I }\end{array}$ & 19.3 & 4.4 & 4.4 \\
\hline Koster dykes Range & $17-52$ & $2.8-4.8$ & 3.5-18.3 \\
\hline N-type MORB AAR & $17-78$ & $2.2-4.2$ & $4.6-23$ \\
\hline N-type MORB SWIR & $17-64$ & $1.8-3.6$ & $8-22$ \\
\hline T-type MORB AAR & $8.8-15.5$ & $3.1-4.7$ & $1.9-4.3$ \\
\hline T-type MORB SWIR & $7.7-11.8$ & 3.3-7.1 & $1.3-3.0$ \\
\hline
\end{tabular}

AAR: American Antarctic Ridge

SWIR: Southwest Indian Ridge (le Roex et al. 1985)

values for Least Differentiated Koster Dyke and Mean Koster Dyke, Sector I, taken from Hageskov (1987). The CIPW weight norms are calculated with the ratio of $\mathrm{Fe}_{2} \mathrm{O}_{3} / \mathrm{FeO}$ found by analysis (first column) as well as with this ratio adjusted to 0.15 (second column).

41197 is considerably higher than Mean Koster Dyke in $\mathrm{MgO}$ and somewhat lower in $\mathrm{SiO}_{2}, \mathrm{TiO}_{2}, \mathrm{CaO}$ and $\mathrm{K}_{2} \mathrm{O}$.

41197 contains $8.5 \%$ olivine phenocrysts, and if the composition of these phenocrysts is deducted from the analysis of 41197 , complete agreement is obtained with Least Differentiated Koster Dyke (personal information B. Hageskov). Least Differentiated Koster Dyke is the average of 41155 and 41166 (Hageskov 1987).

\section{Trace elements}

Trace elements were analysed directly on pressed powder pellets by $\mathbf{J}$. Bailey, Department of Petrology, University of Copenhagen, by X-ray fluorescence using a Phillips PW 1400 (funded by the Danish Natural Science Research Council) and the techniques of Norrish \& Chappel (1977).

The results are shown in table 7 together with the values for Least Differentiated Koster Dyke and Mean Koster Dyke from Hageskov (1987). $\mathrm{Zr} / \mathrm{Nb}, \mathrm{Zr} / \mathrm{Y}$ and $\mathrm{Y} / \mathrm{Nb}$ ratios are shown not only for these dykes, but also for both N-type and T-type MORB from the American 
Antarctic Ridge and the Southwest Indian Ridge (le Roex et. al. 1985).

It is seen that the differences in trace elements are less between 41197 and Least Differentiated Koster Dyke than between 41197 and Mean Koster Dyke.

$\mathrm{Cr}$ and $\mathrm{Ni}$ in 41197 are more than twice as high as in Mean Koster Dyke, whereas the value for $\mathrm{V}$ is only $70 \%$ of that in Mean Koster Dyke. Also Ba, Sr, Y and $\mathrm{Zr}$ are somewhat lower in 41197 than in Mean Koster Dyke.

Based on the ratios $\mathrm{Zr} / \mathrm{Nb}, \mathrm{Zr} / \mathrm{Y}$ and $\mathrm{Y} / \mathrm{Nb}$, Hageskov (1987) suggested that the Koster dykes are N-type MORB. As regards 41197 however, $\mathrm{Zr} / \mathrm{Y}$ and $\mathrm{Y} / \mathrm{Nb}$ are in better agreement with T-type MORB than with $\mathrm{N}$ type MORB.

\section{Conclusions}

Ilmenite as free grains in 41197 has a composition quite similar to that in other Koster dykes from sector I. Apart from their small content of $\mathrm{Cr}$, the ilmenite lamellae in 41197 also show good agreement with those in the other Koster dykes from sector I, but there are small but significant differences between the ilmenite lamellae in different grains within 41197.

The titanomagnetite groundmass in 41197 is strikingly richer in $\mathrm{Cr}, \mathrm{Al}$ and $\mathrm{Mn}$ than in the other Koster dykes from sector I and generally somewhat richer in $\mathrm{Mg}$ and $\mathrm{V}$. In the titanomagnetite groundmass there also are small but significant differences between the different grains.

Spinel rims are clearly poorer in $\mathrm{Cr}$ and richer in $\mathrm{Al}$, $\mathrm{Mg}$ and $\mathrm{Zn}$ than spinel cores.

Haggerty (1976) describes spinel from Icelandic lavas where $\mathrm{Cr}$ as well as $\mathrm{Al}$ decrease from core to rim. This is in contrast to 41197 where $\mathrm{Cr}$ decreases from core to rim but $\mathrm{Al}$ increases. The behaviour of 41197 , however, is in agreement with what Sigurdsson (1977) calls "normal" zoning involving decrease in $\mathrm{Cr} / \mathrm{Cr}+\mathrm{Al}$ from core to rim.

The zoning in 41197 seems not to be continuous but involves only an outer rim. This fact and the fact that no such rim is found in grain 1 with only incipient replacement might indicate that the rims are a result of replacement, because elements not wanted by the replacing titanomagnetite are being concentrated at the border between spinel and titanomagnetite.

Ilmenite and titanomagnetite crystallised in equilibrium at between $991^{\circ} \mathrm{C}$ and $1104^{\circ} \mathrm{C}$ and at $\mathrm{fO}_{2}$ between $10^{-12.9}$ and $10^{-11.2}$, which is very close to the WM buffer curve. There does not seem to be any correlation between temperature and degree of replacement.

As regards whole rock analyses the deviations in major element contents and the content of $\mathrm{Ni}$ are obviously due to the olivine phenocrysts, and the richness in $\mathrm{Cr}$ is caused by the Cr-spinels.

\section{Acknowledgements}

The Jeol Superprobe on which the analyses were carried out was bought with funds from the Danish Natural Science Research Council, and is run under the supervision of J. Rønsbo, Department of Mineralogy, University of Copenhagen, whose assistance with the analyses is greatly appreciated. Thanks are due to T.C.R. Pulvertaft for kindly improving the English of the manuscript, and to the referees for valuable suggestions.

\section{Dansk sammendrag}

I afhandlingen om udviklingen af Fe-Ti-oxiderne i Koster dyke sværmen under amfibolitfacies metamorfose (Jensen 1990) blev en af Koster gangene fra sektor I, 41197, udeladt fordi de kubiske Fe-Ti-oxider afveg fra alle de øvrige gange. Denne gang er olivinporfyrisk, og i dette arbejde er såvel Fe-Ti-oxiderne som olivinen undersøgt ved hjælp af mikrosondeanalyser.

Fe-Ti-oxiderne i 41197 består dels af ilmenit i frie korn og dels af titanomagnetit med afblandingslameller af ilmenit. Nogle af titanomagnetitkornene har en kerne af grå spinel med en lidt mørkere rand ud mod titanomagnetiten (fig. 1), andre korn består overvejende af spinel, men det ses tydeligt at spinellen replaceres af titanomagnetit (fig. 2). Der ses også spinelkorn med mere fremskreden replacering af titanomagnetit (fig. 3).

Spinelanalyserne er vist i tabel 1 . Sammensætningen varierer fra ferrospinel over ferrochromspinel til ferroferrichromspinel (Zhelyazkova-Panayotova 1971). Med undtagelse af det korn der viser den svageste replacering (fig. 2) har spinelkornene en ydre rand der er rigere på $\mathrm{Mg}, \mathrm{Al} \operatorname{og} \mathrm{Zn}$ og fattigere på $\mathrm{Cr}$ og $\mathrm{Fe}^{+++}$end spinelkernen.

Ilmenitanalyserne er vist $i$ tabel 2 . De frie korn har en sammensætning der svarer fuldstændigt til ilmeniten i de $\emptyset$ vrige Koster gange fra sektor I. Bortset fra et lille indhold af $\mathrm{Cr}$ viser ilmenitlamellerne også god overensstemmelse med ilmenitlamellerne i de $\emptyset$ vrige Koster gange fra sektor I, men der er små, men signifikante forskelle mellem ilmenitlamellerne $i$ de forskellige korn.

Analyser af titanomagnetitgrundmassen er vist $i$ tabel 3. Her er også små, men signifikante forskelle mellem de enkelte korn. Sammensætningen af titanomagnetiten varierer fra ferroferrit til ferrochromferrit (Zhelyazkova-Panayotova 1971).

Tabel 4 viser den beregnede sammensatning af den oprindelige titanomagnetit, inden ilmenitlamellerne dannedes ved oxidation af ulvöspinel.

Tabel 5 viser olivinanalyser opdelt i store og små strøkorn samt grundmassekorn.

Tabel 6 og 7 viser bjergartsanalyser af henholdsvis 
hoved- og sporelementer. Til sammenligning er også anført værdierne for mindst differentierede Koster dyke og gennemsnitlige Koster dyke fra sektor I fra Hageskov (1987). 41197 indeholder 8,5\% olivinstrøkorn, og hvis sammensætningen af disse strøkorn fratrækkes anaIysen af 41197 fremkommer der fuldstændig overensstemmelse med mindst differentierede Koster dyke for hovedelementerne. Den afvigende sammensætning af 41197 skyldes således olivinstrøkornene. Det høje sporelementindhold af $\mathrm{Ni}$ og $\mathrm{Cr}$ skyldes formentlig henholdsvis olivinstrøkornene og chromspinellerne.

Temperatur og ilttryk for den samtidige krystallisation af ilmenit og titanomagnetit er bestemt til $991^{\circ} \mathrm{C}-1104^{\circ} \mathrm{C}$ og $10^{-12.9}-10^{-11.2}$.

\section{References}

Andersen, D. J. \& Lindsley, D. H. 1988. Internally consistent solution models for Fe-Mn-Ti oxides: Fe-Ti oxides. Amer. Miner. 73: 714-726.

Finger, L. W. 1972. The uncertainty in the calculated ferric iron content of a microprobe analysis. Carnegie Inst. Wash. Yearb. 71: 600-603.

Ghiorso, M.S. \& Sack, R. O. 1991. Fe-Ti oxide geothermometry: thermodynamic formulation and the estimation of intensive variables in silicic magmas. Contrib. Mineral. Petrol. 108: 485-510.
Hageskov, B. 1984. Magnetic susceptibility used in mapping of amphibolite facies recrystallisation in basic dykes. Tectonophysics 108: 339-351.

Hageskov, B. 1985. Constrictional deformation of the Koster dyke swarm in a ductile sinistral shear zone, Koster islands, SW Sweden. Bull. geol. Soc. Denmark 34: 151-197.

Hageskov, B. 1987. Tholeiitic dykes and their chemical alteration during amphibolite facies metamorphism: The Kattsund-Koster dyke swarm SE Norway - W Sweden. Sver. Geol. Unders. Ser. C, Nr. 817: 1-61.

Haggerty, S. E. 1976. Oxidation of opaque mineral oxides in basalts. 1-100 In Rumble, D. (ed.) Oxide Minerals. Min. Soc. Amer., Short course notes. Southern Printing Company, Virginia.

Jensen, Aa. 1990. Development of the Fe-Ti-oxides in the Koster dyke swarm during amphibolite facies metamorphism. Bull. geol. Soc. Denmark 38: 109-118.

Le Roex, A. P., Dick, H. J.B., Reid, A.M., Frey, F. A. \& Erlank, A. J. 1985. Petrology and geochemistry of basalts from the American-Antarctic Ridge, Southern Ocean: implications for the westward influence of the Bouvet mantle plume. Contrib. Mineral. Petrol. 90: 367-380.

Norrish, K. \& Chappel, B. W. 1977. X-ray fluorescence spectrometry 201-272 In Zussman, J. (ed.) Physical methods in determinative mineralogy, 2. ed. Academic Press, London.

Sigurdsson, H. 1977. Spinels in Leg 37 basalts and peridotites: Phase chemistry and zoning. Initial Reports of the Deep Sea Drilling Project 37: 883-891.

Zhelyazkova-Panayotova, M. 1971. On a rational classification of the spinel group from ultrabasic rocks. Mineral. Soc. Japan, Special Paper 1: 174-179. 